ISSN 0258-7122 (Print), 2408-8293 (Online)

Bangladesh J. Agril. Res. 41(1): 103-113, March 2016

\title{
FIELD PERFORMANCE OF BARI UREA SUPER GRANULE APPLICATOR
}

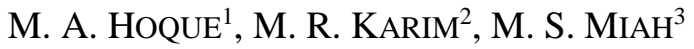 \\ M. A. RAHMAN ${ }^{4}$ AND M. M. RAHMAN ${ }^{5}$
}

\begin{abstract}
Field performance of BARI Urea Super Granule (USG) applicator was evaluated on BARI research stations (Gazipur, Pabna, and Barisal) and farmer's field (Pabna, Barisal, Magura,Narshingdi,Jhenadah, Sirajgang, Rajbari and Jhalkathi) during the boro season of 2012-13. The applicator was tested with four treatments- application of USG by hand $(165 \mathrm{~kg} / \mathrm{ha})$, application of USG by BARI USG applicator $(165 \mathrm{~kg} / \mathrm{ha})$, application of prilled urea at USG rate $(165 \mathrm{~kg} / \mathrm{ha})$ and application of prilled urea at farmers practice. In the farmer's field, USG applicators were evaluated with the traditional broadcasting of granular urea. Similar yield of rice was obtained from machine and hand application of USG in all locations. Higher yield of rice was obtained from USG than granular urea. During field test, average field capacity and efficiency of the applicator were $0.138 \mathrm{ha} / \mathrm{h}$ and $81 \%$, respectively. Considering custom hiring, the net income per year was Tk. 71750 and the payback period was 3 days. The price of the applicator is Tk. 3500 .
\end{abstract}

Keywords: USG applicator, Field capacity, Field efficiency, Payback period.

\section{Introduction}

Urea has emerged as an important nitrogen fertilizer for rice. Statistics indicates that about $80 \%$ of urea is used for rice production. But only 15 to $35 \%$ of the total applied nitrogen is used by the rice plant (Prasad and Datta, 1979). The low level of nitrogen recovery by rice plant is generally caused by huge losses of the soilwater-plant complex. Nitrogen loss processes are due to ammonia volatilization, de-nitrification, runoff, seepage, and leaching. Thus there is a great need to improve nitrogen use efficiency for rice production. Due to excessive loss of nitrogen, farmers in Bangladesh have not been able to make more effective use of fertilizer to boost their rice yields. In the present (granular/prilled urea) method of application, only $40 \%$ of the applied urea is used by the plant and the remaining $60 \%$ is lost by air, water or leaching under the ground (Iqbal, 2009). Another statistics showed that two out of three bags of urea go un-used in wet land rice production (Amit, 2011).With deep placement methods, fertilizers are placed in the soil irrespective of the position of seed, seedling or growing plants before sowing or after sowing the crops (Datta and Fillery, 1983). Deep placement of

${ }^{1}$ Senior Scientific Officer and ${ }^{3-5}$ Scientific Officer, F M P Engineering Division, BARI, Gazipur; ${ }^{2}$ Scientific Officer, OFRD, Pabna, Bangladesh. 
nitrogenous fertilizer $(\mathrm{N})$ is an alternative for increasing the $\mathrm{N}$ use efficiency of wetland rice besides minimizing the adverse effects of fertilizers on the environment (Bautista et al. 2001). On the contrary, deep placement of urea is environment friendly having minimal loss (Ahamed, 2012). Bangladesh has substantially increased its rice production through increased use of inorganic fertilizer. The nature and degree of loss depends upon soil, climatic conditions, nitrogen fertilizer and water management practices. Much effort has been made to improve fertilizer use efficiencies in lowland rice production. Deep placement of nitrogen fertilizer into the anaerobic soil zone is an effective method to reduce volatilization loss. At present, Urea Super Granule (USG) has been started to be used in puddled rice field and found to be economic and effective method of urea fertilizer application in rice field. Hand placement of USG of 1.8-2.7 g sizes into soil of flood water has been resulted less loss of nitrogen, greater nitrogen recovery and higher yield than conventional nitrogen application method (Diamond, 1985). Instead of normal dose of $247 \mathrm{~kg}$ of granular urea, only 165 $\mathrm{kg} / \mathrm{ha}$ of USG is required (35\% less) and it increases rice yield up to 20\% (Hoque, 2008). Depending on agroclimate and nitrogen use, deep-placed USG can save urea fertilizer up to $65 \%$ with an average of $33 \%$ and increase grain yields up to $50 \%$ with an average of $15 \%$ to $20 \%$ over the same amount of split-applied nitrogen as prilled urea, especially in the lower range of nitrogen rates (Savant and Stangel, 1990). But, deep placement of USG by hand requires more labour and cost. Labor shortage in rice production is one of the major constraints which cause due to migration of people to town and need mechanization for rice production (Mohammada et al., 2011). The hand placement of USG is labor intensive and very slow i.e. 0.07 to 0.12 ha/workday (Savant et al., 1992). Also hand placement of USG is tedious work and caused back pain.

Unfortunately, farmers have not been able to be benefited from these findings, primarily because they have no suitable fertilizer placement equipment. Cost of fertilizer is increasing day by day. Efforts should be made to develop a low cost, efficient fertilizer application machine for placing the fertilizer at required depths for different crops. Thus fertilizer use efficiency will be high, resulting in higher yield and lower production cost. To minimize nitrogen loss, USG application may be a good technology to increase rice yield as well as the reduction of production cost. Minimum effort has been made in the county to develop a fertilizer applicator machine for improving fertilizer use efficiency. To solve the problem of USG placement by hand, a manually operated push type fertilizer applicator for puddled rice field has been developed in Farm Machinery and Postharvest Process (FMP) Engineering Division of Bangladesh Agricultural Research Institute (BARI) (Wohab et al., 2009). DAE and IFDC in collaboration with BARI have been demonstrating this technology in 68 Upazilas (The daily Star, 27 June, 2011). This study was therefore, undertaken to evaluate the field performance of BARI USG the applicator. 


\section{Materials and Method}

\section{Operation of the USG applicator}

The skids of the applicator were placed between rows of rice plants keeping two rows of rice plants between the skids. Half of the fertilizer hoppers were filled with Urea Super Granule (USG). The applicator was then pushed forward manually. This made the cage wheel and the metering devices rotated. During rotation of the metering devices, it carries USG into the pockets and delivers them to the furrow openers. During forward movement of the applicator, the skids helped float the machine. The applicator dropped the USG at $20 \mathrm{~cm}$ row spacing, at about $38 \mathrm{~cm}$ spacing along the row and at 5-6 $\mathrm{cm}$ depth. Furrow closers closed the furrows providing anaerobic condition for the USG. The total width of application was adjustable $(70 \mathrm{~cm}-100 \mathrm{~cm})$. The field operation of the machine is shown in Fig. 1.

\section{Field performance test}

The field performance test of the applicator was done in the experimental field of FMP Engineering division, Gazipur; Agricultural Research Station (ARS), Pabna and Regional Agricultural Research Station, Rahmatpur, Barisal during boro season of 2012-13. The USG applicator was operated at 8 days after transplanting rice seedlings. The applicator was used in $2-5 \mathrm{~cm}$ of standing water. The machine was operated at an average speed of $1.50 \mathrm{~km} / \mathrm{h}$. One operator could comfortably run the machine. The experiment was laid out in RCB design with the following treatments and three replications.

$$
\begin{aligned}
& \mathrm{T}_{1}=\text { Application of USG (urea super granule) by hand }(165 \mathrm{~kg} / \mathrm{ha}) \\
& \mathrm{T}_{2}=\text { Application of USG (urea super granule) by the machine }(165 \mathrm{~kg} / \mathrm{ha}) \\
& \mathrm{T}_{3}=\text { Application of prilled urea at USG rate }(165 \mathrm{~kg} / \mathrm{ha}) \\
& \mathrm{T}_{4}=\text { Application of prilled urea at farmers' practice }(287 \mathrm{~kg} / \mathrm{ha})
\end{aligned}
$$

Each plot size was $5.5 \times 5 \mathrm{~m}$ in Gazipur; $10 \times 8 \mathrm{~m}$ in Pabna and $17.5 \mathrm{~m} \times 12.5 \mathrm{~m}$ in Barisal. The soil type was clay loam, loam, and sandy loam in Gazipur, Pabna, Barisal and Magura, respectively. The rice variety was BRRI dhan 28. The ages of seedlings were 35,30 and 36 days in Gazipur, Pabna, and Barisal, respectively. The date of planting of seedlings in Gazipur was 10 March 2013, in Pabna was 14 February 2012 and in Barisal was 19 April, 2013. Row to row and hill to hill distance was $20 \mathrm{~cm}$. For counting missing percentage of USG for the applicator, required numbers of USG was calculated for each plot and after application numbers of remain USG in the hopper was counted. TSP $51 \mathrm{~kg} / \mathrm{ha}$, MOP $70 \mathrm{~kg} / \mathrm{ha}$, Zinc $50 \mathrm{~kg} / \mathrm{ha}$ and Boron $5 \mathrm{~kg} / \mathrm{ha}$ were applied as basal dose 
before final land preparation. Full dose of USG was applied at 8 DAS (days after transplanting). One third prilled urea was applied at 8 days after transplanting and second one third urea was applied 40 DAS. The rest one third urea was applied at 55-60 DAS. Weeding was done manually at 35 DAS. Irrigation was applied when the soil moisture content became below the saturation condition. The insecticides were applied as and when necessary.

To compare field performance of the USG applicator with manual broadcasted prilled urea application, total 22 crop cuts were taken from different locations of the country. Farmers were selected who has cultivated BRRI dhan 28 and applied both USG by BARI applicator and broadcasted prilled urea. Each set of data was collected from Babugang and Gouranadi upzilla of Barisal, Shibpur upzilla of Narshingdi district, Baliakandi and Pangsa upzilla of Rajbari district, Sailokopaupzilla of Jhinaidah district. Two sets of data were collected from each upzilla of Sujanagar and Sathia of Pabna, Shahajadpur and Ullapara of Sirajgang, Jhalkathisadar and Rajapur of Jhalkathi, Salikha and Sreepur of Magura. Mean values were analyzed statistically and mean separation was done at $5 \%$ level by DMRT. Incase of USG applicator and Broadcast method mean values were analysed using test. A list of farmers selected are shown in Appendix 1 and Appendix 2.

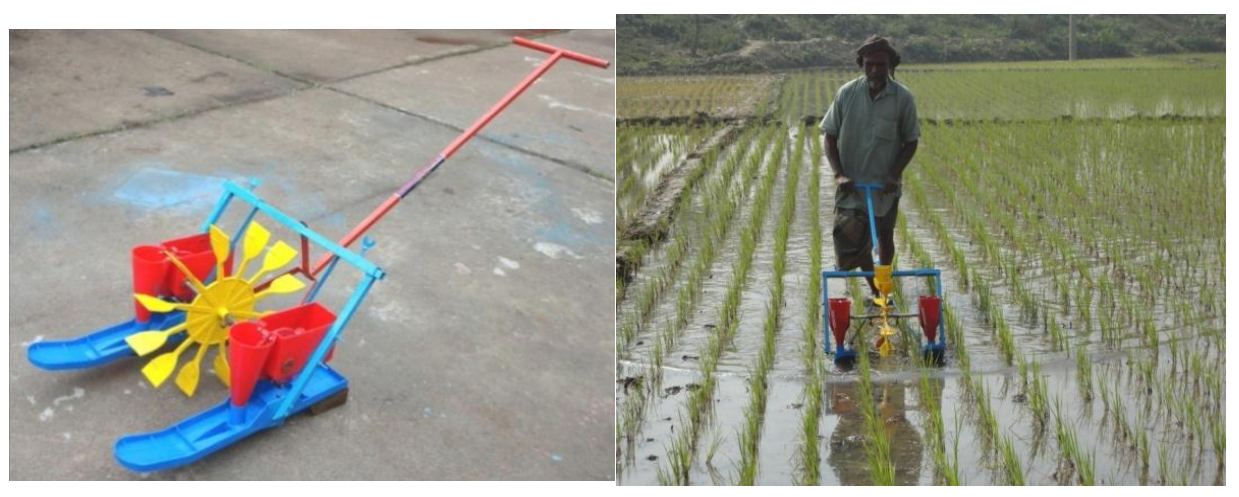

Fig. 1 BARI USG Applicator Fig.2 Operation of USG Applicator in field

\section{Results and Discussion}

Performance of USG applicator at different locations is shown in Table 1. Average operating time, field capacity and operator efficiency of USG applicator were $7.22 \mathrm{~h} / \mathrm{ha}, 0.138 \mathrm{ha} / \mathrm{h}, 81 \%$, respectively. Urea saved over farmers' practice of prilled urea was $122 \mathrm{~kg} / \mathrm{ha}$. In case of hand application of USG, operating time per hector was $35.97 \mathrm{~h}$. USG applicator can save $80 \%$ operation time and $78 \%$ cost of operation than hand application of USG. During field operation missing of USG dropping was very low as $1.0 \%$. 
Table 1. Performance of BARI Urea Super Granule (USG) applicator at different locations

\begin{tabular}{lccccl}
\hline \multicolumn{1}{c|}{ Parameter } & Gazipur & Pabna & Barisal & Mean \\
\hline USG Applicator: & & & & \\
Operating time, h/ha & 7.02 & 7.43 & 7.20 & 7.22 \\
Field capacity, ha/h & 0.143 & 0.135 & 0.138 & 0.138 \\
Operator efficiency, \% & 83 & 80 & 81 & 81.33 \\
USG used, kg/ha & 165 & 165 & 165 & 165 \\
Urea saved over prilled urea, kg/ha & 122 & 122 & 122 & 122 \\
Missing of USG dropping, \% & 0.98 & 1.2 & 1.0 & 1.06 \\
Cost, Tk/ha & 350 & 250 & 325 & 308.33 \\
Hand Application: & & & & \\
Operating time, h/ha & 33.33 & 39.16 & 35.42 & 35.97 \\
Cost, Tk/ha & 1458 & 1224 & 1439 & 1373.66 \\
Comparison: & & & & \\
Time saved over hand application, \% & 80 & & & \\
Cost saved over hand application, \% & 78 & & & \\
\hline
\end{tabular}

The yield and yield contributing factors of different urea application method in boro rice in Gazipur is shown in Table 2. There was no significant difference in yield of treatment $T_{1}$ and $T_{2}$. The highest yield of rice was obtained from treatment $T_{2}$ followed by $T_{1}$ and $T_{4}$ and the lowest yield was found from treatment $T_{3}$. This may be due to significantly higher number of tillers per hill and number of fill grain per panicle in treatment $T_{2}$ than other treatments

Table 2. Yield and yield contributing factors for different urea application method in boro rice in Gazipur

\begin{tabular}{l|c|c|c|c|c|c|c|c}
\hline Treatment & $\begin{array}{c}\text { No of } \\
\text { hill/m² }\end{array}$ & $\begin{array}{c}\text { No. of } \\
\text { tillers/hill }\end{array}$ & $\begin{array}{c}\text { Plant } \\
\text { height } \\
(\mathrm{cm})\end{array}$ & $\begin{array}{c}\text { Length } \\
\text { of } \\
\text { panicle } \\
(\mathrm{cm})\end{array}$ & $\begin{array}{c}\text { No. of } \\
\text { fill grain } \\
/ \text { panicle }\end{array}$ & $\begin{array}{c}\text { No. of } \\
\text { unfilled } \\
\text { grain / } \\
\text { panicle }\end{array}$ & $\begin{array}{c}1000 \\
\text { grain } \\
(\mathrm{g})\end{array}$ & $\begin{array}{c}\text { Grain } \\
\text { yield } \\
(\mathrm{t} / \mathrm{ha})\end{array}$ \\
\hline $\mathrm{T}_{1}$ & 19.33 & $16.83 \mathrm{a}$ & $72.40 \mathrm{ab}$ & $20.19 \mathrm{a}$ & $71.40 \mathrm{a}$ & $14.33 \mathrm{~b}$ & $24.60 \mathrm{a}$ & $5.35 \mathrm{ab}$ \\
$\mathrm{T}_{2}$ & 19.00 & $16.65 \mathrm{a}$ & $78.40 \mathrm{a}$ & $20.70 \mathrm{a}$ & $73.15 \mathrm{a}$ & $15.93 \mathrm{~b}$ & $24.86 \mathrm{a}$ & $5.57 \mathrm{a}$ \\
$\mathrm{T}_{3}$ & 19.00 & $13.23 \mathrm{ab}$ & $70.20 \mathrm{ab}$ & $17.77 \mathrm{~b}$ & $50.40 \mathrm{~b}$ & $31.20 \mathrm{a}$ & $22.16 \mathrm{c}$ & $4.83 \mathrm{c}$ \\
$\mathrm{T}_{4}$ & 18.66 & $12.13 \mathrm{~b}$ & $68.96 \mathrm{~b}$ & $17.38 \mathrm{~b}$ & $62.46 \mathrm{ab}$ & $22.80 \mathrm{ab}$ & $23.06 \mathrm{~b}$ & $5.07 \mathrm{bc}$ \\
\hline
\end{tabular}

Similar letter(s) in same column does not differ significantly each other at $5 \%$ level by DMRT. 
Yield and yield contributing factor for different urea application method in boro rice in Pabna is given in Table 3. It is observed from the table that there were no significant differences of number of hill per meter square, plant height, length of panicle, and numbers of unfilled grain per panicle of rice among the treatments. Number of tillers per hill, number of fill grain per panicle and 1000 grain weight were significantly lower in treatment $\mathrm{T}_{3}$ than other treatments. It is also observed from the table that significantly highest yield was found for USG application than that of prilled urea. There was no significant difference of grain yield between machine and hand application of USG.

Table 3 Yield and yield contributing factors for different urea application methods in boro rice in Pabna

\begin{tabular}{l|c|c|c|c|c|c|c|c}
\hline Treatment & $\begin{array}{c}\text { No of } \\
\text { hill/m }\end{array}$ & $\begin{array}{c}\text { No. of } \\
\text { tillers/hill }\end{array}$ & $\begin{array}{c}\text { Plant } \\
\text { height } \\
(\mathrm{cm})\end{array}$ & $\begin{array}{c}\text { Length } \\
\text { of } \\
\text { panicle } \\
(\mathrm{cm})\end{array}$ & $\begin{array}{c}\text { No. of fill } \\
\text { grain / } \\
\text { panicle }\end{array}$ & $\begin{array}{c}\text { No. of } \\
\text { unfilled } \\
\text { grain / } \\
\text { panicle }\end{array}$ & $\begin{array}{c}1000 \\
\text { grain (g) }\end{array}$ & $\begin{array}{c}\text { Grain } \\
\text { yield } \\
\text { (t/ha })\end{array}$ \\
\hline $\mathrm{T}_{1}$ & 25.33 & $11.36 \mathrm{a}$ & 92.46 & 23.64 & $126.60 \mathrm{a}$ & 13.00 & $27.00 \mathrm{a}$ & $5.21 \mathrm{a}$ \\
$\mathrm{T}_{2}$ & 15.33 & $11.76 \mathrm{a}$ & 94.33 & 23.430 & $125.43 \mathrm{a}$ & 14.43 & $26.66 \mathrm{a}$ & $5.10 \mathrm{a}$ \\
$\mathrm{T}_{3}$ & 26.66 & $9.90 \mathrm{~b}$ & 94.41 & 22.90 & $112.56 \mathrm{~b}$ & 14.50 & $23.00 \mathrm{~b}$ & $4.45 \mathrm{~b}$ \\
$\mathrm{~T}_{4}$ & 123.66 & $11.43 \mathrm{ab}$ & 89.99 & 23.00 & $121.13 \mathrm{ab}$ & 12.23 & $24.67 \mathrm{ab}$ & $5.08 \mathrm{a}$ \\
\hline
\end{tabular}

Similar letter(s) in same column does not differ significantly each other at $5 \%$ level by DMRT.

Table 4. Yield and yield contributing factors for different urea application method in rice in Barisal

\begin{tabular}{l|c|c|c|c|c|c|c|c}
\hline Treatment & $\begin{array}{c}\text { No of } \\
\text { hill/m }\end{array}$ & $\begin{array}{c}\text { No. of } \\
\text { tillers/ } \\
\text { hill }\end{array}$ & $\begin{array}{c}\text { Plant } \\
\text { height } \\
(\mathrm{cm})\end{array}$ & $\begin{array}{c}\text { Length } \\
\text { of } \\
\text { panicle } \\
(\mathrm{cm})\end{array}$ & $\begin{array}{c}\text { No. of } \\
\text { fill grain } \\
/ \text { panicle }\end{array}$ & $\begin{array}{c}\text { No. of } \\
\text { unfilled } \\
\text { grain / } \\
\text { panicle }\end{array}$ & $\begin{array}{c}1000 \\
\text { grain } \\
(\mathrm{g})\end{array}$ & $\begin{array}{c}\text { Grain } \\
\text { yield } \\
(\mathrm{t} / \mathrm{ha})\end{array}$ \\
\hline $\mathrm{T}_{1}$ & 18.66 & 16.65 & $37.66 \mathrm{ab}$ & 20.33 & $132.33 \mathrm{a}$ & $4.66 \mathrm{~b}$ & $32.00 \mathrm{a}$ & $6.16 \mathrm{a}$ \\
$\mathrm{T}_{2}$ & 19.33 & 16.83 & $40.06 \mathrm{a}$ & 20.16 & $129.33 \mathrm{a}$ & $4.00 \mathrm{~b}$ & $31.20 \mathrm{a}$ & $6.04 \mathrm{a}$ \\
$\mathrm{T}_{3}$ & 18.66 & 12.80 & $35.83 \mathrm{~b}$ & 19.66 & $114.00 \mathrm{~b}$ & $6.33 \mathrm{~b}$ & $29.80 \mathrm{~b}$ & $5.59 \mathrm{~b}$ \\
$\mathrm{~T}_{4}$ & 19.33 & 13.56 & $39.13 \mathrm{ab}$ & 20.00 & $109.66 \mathrm{a}$ & $9.66 \mathrm{a}$ & $30.80 \mathrm{~b}$ & $5.70 \mathrm{~b}$ \\
\hline
\end{tabular}

Similar letter(s) in same column does not differ significantly each other at $5 \%$ level by DMRT.

Table 4 show the yield and yield contributing factors for different area application method in boro rice in Barisal. Significantly the highest plant height was observed for treatment $T_{2}$ than other treatments. But the plant heights of treatment $T_{1}$ and $T_{2}$ were statistically alike. Treatment $T_{3}$ and $T_{4}$ were also statistically alike. There were no significant differences of number of hills per square meter, number of tillers per hill, and length of panicle among the treatments. The highest yield of rice was obtained from treatment $T_{1}$ followed by 
$\mathrm{T}_{2}$ and $\mathrm{T}_{4}$ and lowest yield was found from treatment $\mathrm{T}_{3}$. But there was no significant difference between treatment $T_{1}$ and $T_{2}$. Grain yields of treatment $T_{3}$ and $\mathrm{T}_{4}$ were also statistically alike. These results indicated that there was nonsignificant effect of machine and hand application of USG, but machine application method saved time about $80 \%$ and cost of application about $77.84 \%$.

Comparative performance of yield and yield contributing characters of boro rice urea applied by BARI USG applicator and broadcasted is shown in Table 5. The detailed data obtained at farmer's field are presented in Appendix 1 and Appendix 2. There was no significant difference of number of hill per meter square, plant height and number of unfilled grain per panicle between the fields where urea were applied by USG applicator and broadcasted. Significantly higher yield was observed due to higher number of tiller per hill, number of effective tillers per meter square, length of panicle, number of fill grain per panicle and 1000 grain weight. Thus application of USG by BARI applicator contributed to increase the rice production.

Table 5. Comparative performance of yield and yield contributing character of boro rice urea applied by BARI Urea Super Granule (USG) applicator and broadcasted

\begin{tabular}{l|c|c|c|c|c|c|c|c|c}
\hline Treatment & $\begin{array}{c}\text { No of } \\
\text { hill/m² }\end{array}$ & $\begin{array}{c}\text { No. of } \\
\text { tillers/hill }\end{array}$ & $\begin{array}{c}\text { Plant } \\
\text { height } \\
(\mathrm{cm})\end{array}$ & $\begin{array}{c}\text { Effective } \\
\text { tillers/m² }\end{array}$ & $\begin{array}{c}\text { Length } \\
\text { of } \\
\text { panicle } \\
(\mathrm{cm})\end{array}$ & $\begin{array}{c}\text { No. of } \\
\text { fill } \\
\text { grain / } \\
\text { panicle }\end{array}$ & $\begin{array}{c}\text { No. of } \\
\text { unfilled } \\
\text { grain / } \\
\text { panicle }\end{array}$ & $\begin{array}{c}1000 \\
\text { grain } \\
(\mathrm{g})\end{array}$ & $\begin{array}{l}\text { Grain } \\
\text { yield } \\
\text { (t/ha) }\end{array}$ \\
\hline $\begin{array}{l}\text { USG } \\
\text { applicator }\end{array}$ & 29.22 & 422.27 & 93.06 & 409.18 & 25.05 & 146.21 & 17.33 & 21.61 & 7.10 \\
Broadcast & 28.95 & 373.27 & 92.70 & 356.27 & 23.65 & 129.08 & 19.79 & 20.56 & 6.15 \\
\hline t-test & Ns & $*$ & $\mathrm{~ns}$ & $*$ & $*$ & $*$ & $\mathrm{~ns}$ & $*$ & $*$ \\
\hline
\end{tabular}

Table 6. Economic performance of the Urea Super Granule (USG) applicator

\begin{tabular}{lc}
\hline \multicolumn{1}{c}{ Parameters } & Cost \\
\hline Price of the USG applicator, Tk & 3500 \\
Operating area per year, ha & \\
Aus & 05 \\
Aman & 15 \\
Boro & 20 \\
Total Operating time per year, day & 40 \\
Custom hire rate, Tk/ha & 1875 \\
Gross income per year, Tk & 75000 \\
Repair and maintenance cost, Tk/year & 250 \\
Net income per year, Tk & 71750 \\
Payback period, day (Rounded) & 3 \\
\hline
\end{tabular}

Economic performance and payback period of the USG applicator is given in Table 6. If one person engaged him in custom hiring of USG applicator, then the net income per year will be Tk. 71750. Considering capacity of the operator of the applicator was $1 \mathrm{ha} /$ day and labour wage was $500 \mathrm{Tk} /$ day, the payback period of the USG applicator in custom hiring was 3 days. 


\section{Conclusion}

The field performance test of the applicator was satisfactory. Use of the applicator ensured similar yield to hand application of USG in all locations. USG applicator was easy to operate as its weight is $6 \mathrm{~kg}$. It saved about $80 \%$ of USG application time and saved application cost about $78 \%$ than hand application. USG provided higher yield over the granular urea application system. Payback period was 3 days.

\section{References}

Ahamed M. S. 2012. Improvement of guti urea applicator, Department of Farm Power and Machinery, Bangladesh Agricultural University, Mymensingh-2202, Bangladesh.

Amit R. 2011. Research on the next generation of fertilizers. IFDC, Presented at the Syngenta Foundation for Sustainable Agriculture, Basel, Switzerland.

Bautista E. U., M. Koike, D.C. Suministrado, 2001.Mechanical deep placement of nitrogen in wetland rice. J. Agril. Eng. Res. 4(78): 333-346.

Datta S. K. and Fillery I.R.P. 1983. Effect of placement methods on field and recovery of applied nitrogen (15n-labeled urea) in Wetland Rrice. Soil Science. 34, Pp.124-129.

Diamond, R. B. 1985.Status of N deep placement research in Asia.Proceedings of the technical session, Fertilizer $\mathrm{N}$ deep placement for rice.BARC.

Hoque, N. 2008. Saving of taka 250 crores and increasing yield by $20 \%$ by using Goti Urea (Bangla). Hossain, M. T. 1998. USG demonstration result for 1996-97 and 1997-98. Paper presented at the national workshop on Urea Super Granule Technology (USG). BARC, Dhaka, Bangladesh, 25 June.

Iqbal S. H. 2009. Improvement of the existing USG fertilizer applicator, Dept. of Agricultural Engineering, Bangladesh Sheikh MujiburRahman Agricultural University, Gazipur, Bangladesh.7(14), Pp.12-17.

Mohammed S. A., D. Ahmad, O. Jamarei, S. Samsuddin and M. Norhisam.2011. Evaluation of a dual-purpose chemical applicator for paddy fields. Ame. J. Applied Sci. 8(4): 362-367.

Prasad, R and S K Data. 1979. Increasing fertilizer N efficiency in wet land rice. Nitrozen and rice, IRRI, Philipines.

Savant, N. K., and P. J. Stangel. 1990. Deep placement of urea super granules in transplanted rice: Principles and practices. Nutrient Cycling in Agroecosystems. 25(1): 1-83.

Savant, N. K., P. S. Ongkingco, F. D. Garcia, S. S. Dhane, R. R. Khadse, S.A. Chavan, and K. S. Rao. 1992. Agronomic performance of urea briquette applicator in transplanted rice. Nutrient Cycling in Agroecosystems. 32(2): 139-142.

The Daily Star, 27 June 2011, Dhaka, Bangladesh. p. 15,

Wohab, M.A., Islam, M.S., Hoque. M.A., Hossain, M. A. and Ahmed, S. 2009. Design and development of a urea super granule applicator for puddled rice field. J. Agril. Eng. 37/AE: 57-62. 


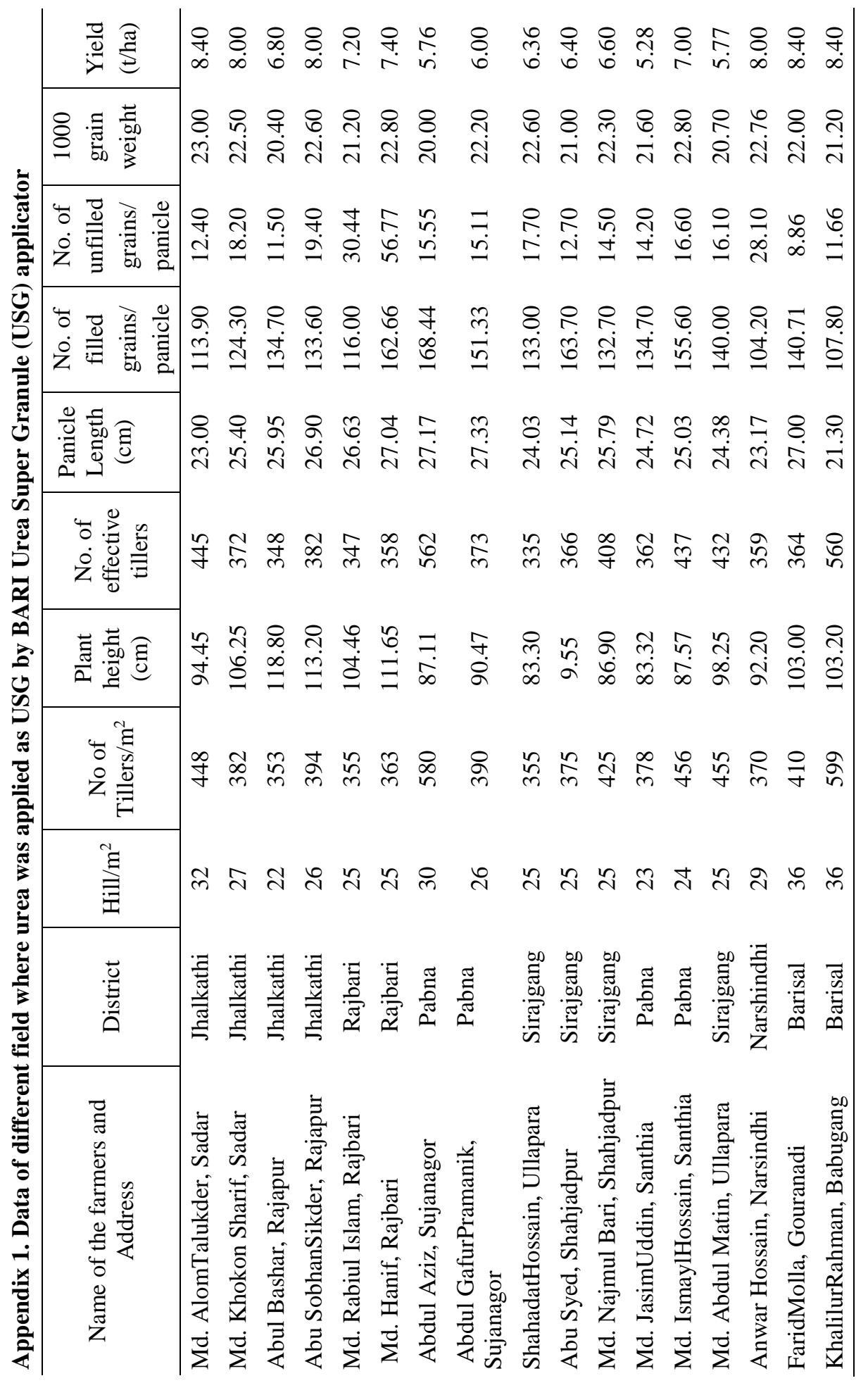




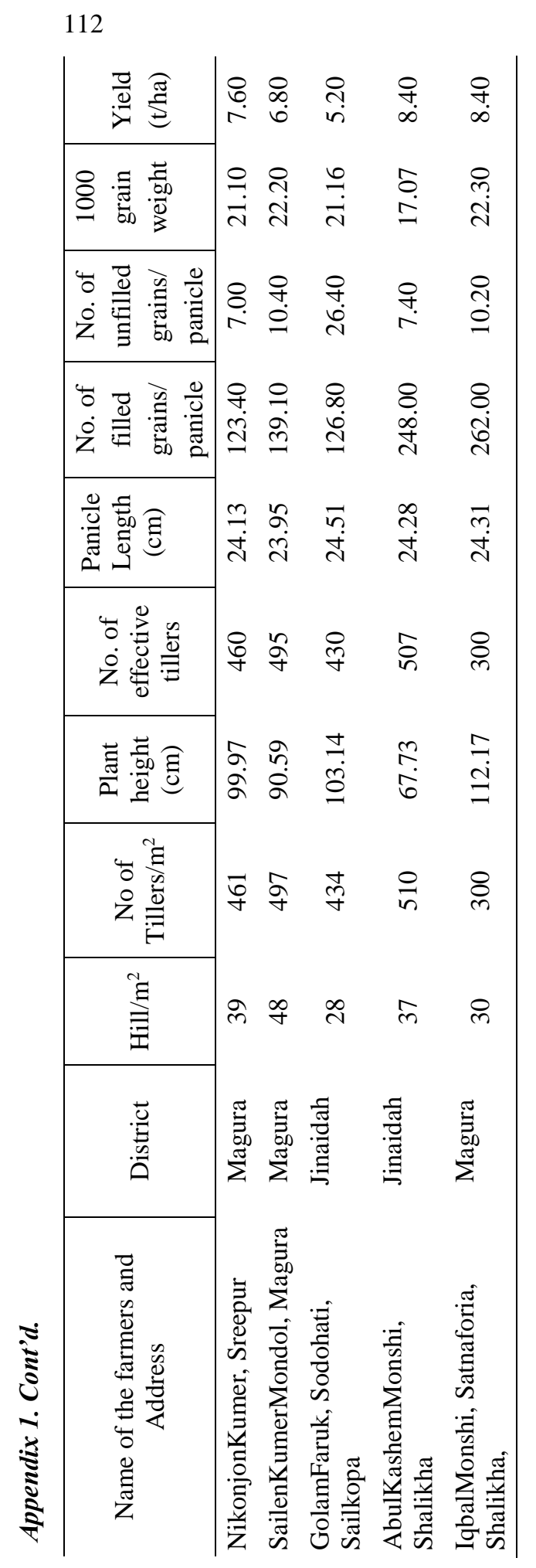

HoQue et al. 
FIELD PERFORMANCE OF BARI UREA SUPER GRANULE APPLICATOR

\begin{tabular}{|c|c|}
\hline 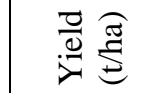 & 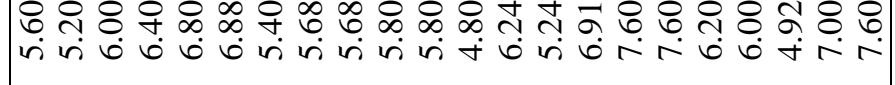 \\
\hline 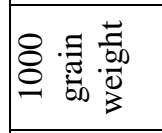 & 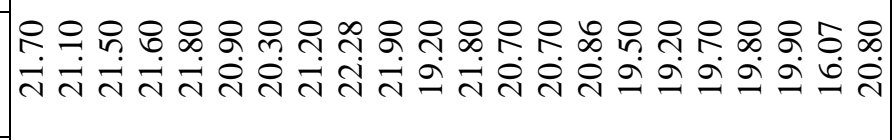 \\
\hline 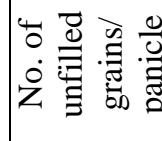 & Fin \\
\hline 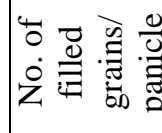 & 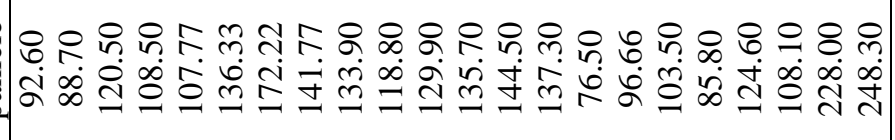 \\
\hline 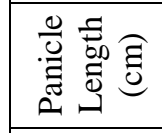 & 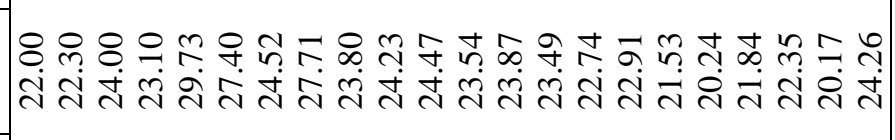 \\
\hline 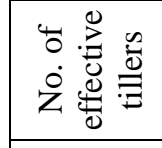 & 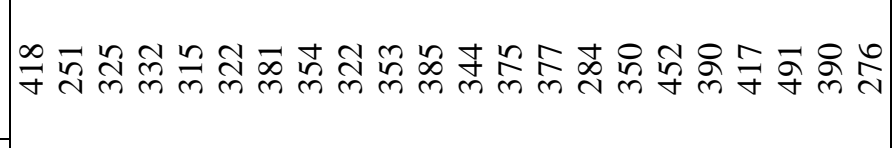 \\
\hline 壳 营莺 & 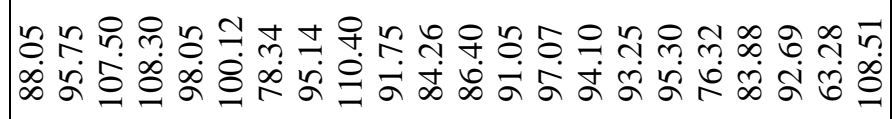 \\
\hline 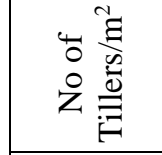 & 하 \& \\
\hline & 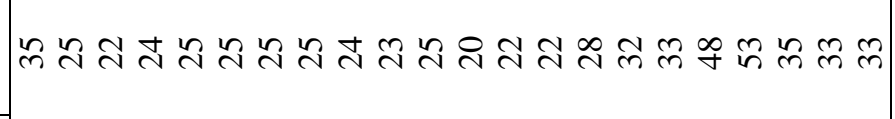 \\
\hline 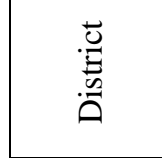 & 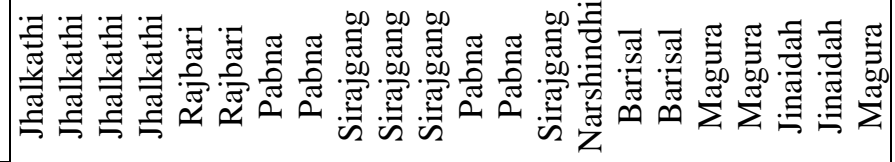 \\
\hline 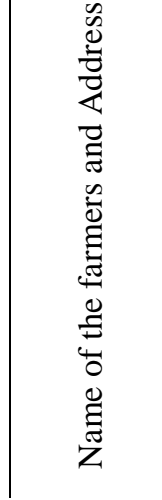 & 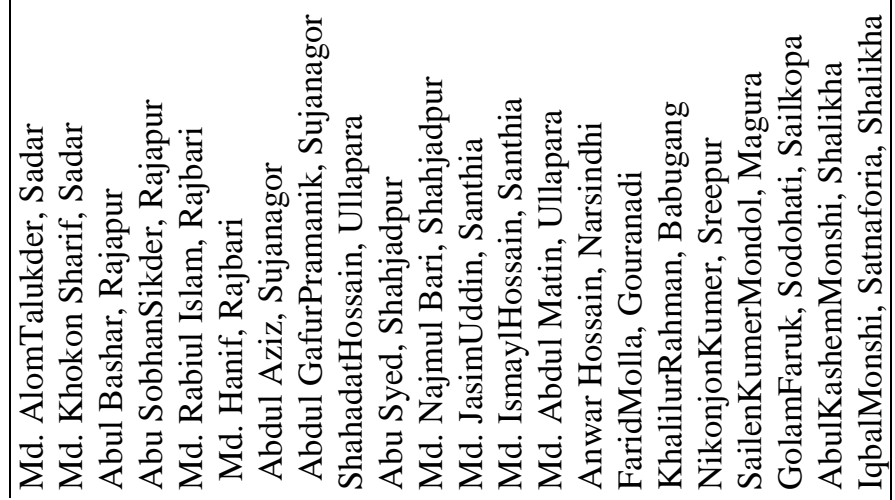 \\
\hline
\end{tabular}

